\title{
EFFICACY OF FEAR APPEALS ON ADOPTION OF COVID-19 PREVENTIVE MEASURES: A CASE OF BODA BODA RIDERS IN NAIROBI COUNTY, KENYA
}

\author{
Kinya K. Kigatiira ${ }^{* 1}$ 伲 \\ ${ }^{* 1}$ Department of Journalism and Communication, Faculty of Media and Communication, \\ Multimedia University of Kenya
}

DOI: https://doi.org/10.29121/granthaalayah.v8.i6.2020.533

Article Type: Case Study

Article Citation: Kinya K. Kigatiira. (2020). EFFICACY OF FEAR APPEALS ON ADOPTION OF COVID19 PREVENTIVE MEASURES: A CASE OF BODA BODA RIDERS IN NAIROBI COUNTY, KENYA. International Journal of Research GRANTHAALAYAH, 8(6), 219 - 228

https://doi.org/10.29121/granthaa layah.v8.i6.2020.533

Received Date: 08 May 2020

Accepted Date: 29 June 2020

\section{Keywords:}

Fear Appeals

Adoption

COVID-19 Preventive Measures

\section{ABSTRACT}

This study was an investigation of the effectiveness of fear appeals on the adoption of COVID-19 preventive measures among boda boda riders in the Nairobi County, Kenya. The problem of the study was that little or no research has been conducted on fear appeals and adoption of COVID-19 preventive measures, hence a gap that demands specific studies to be undertaken to fill it. This study draws from the Health Belief Model (HBM). Case study research design was used because the study focused only on boda boda riders operating in the seventeen constituencies in Nairobi County. Convenience sampling was used to identify the riders who were available and willing to participate in the study. The main data collection tool was telephone interviews. Findings of this study revealed that fear appeals were effective in making boda boda riders in Nairobi County adopt the COVID-19 preventive measures. The boda boda riders' felt that they were susceptible to the coronavirus disease, police arrests, fourteen days mandatory quarantine, motorcycles being impounded and payment of fines, if they did not adopt the COVID-19 preventive measures. Moreover, the riders believed that the virus posed a more serious threat to their health and lives. The operators perceived susceptibility to the threats, elicited high levels of fear. The COVID-19 preventive measures, also, provided the riders with an effective method of changing behavior which they believe will protect them from contracting the virus. This study recommended that in order to motivate the boda boda riders to continue practicing the COVID-19 preventive measures, the government should frequently give the riders masks and hand sanitizers. Further, more communication campaigns should be developed and conducted on COVID19 awareness and prevention among boda boda riders.

\section{INTRODUCTION}

The tactic of using fear-based messages to make people change their behavior and protect them from lifethreatening situations, is a popular persuasive strategy that has been practiced for many years, all over the world. According to Dahl, Frankenberger, and Manchanda (2003) and Thompson, Barnett and Pearceet (2009), it is believed that fear appeals initially emerged in the early 1980s from the clothing industry, in particular Benetton, Calvin Klein and Richard James. Benetton and Calvin Klein clothing companies, used shocking details in their advertisements

(C) 2020 The Author(s). This is an open access article distributed under the terms of the Creative Commons Attribution License, which permits unrestricted use, distribution, and reproduction in any medium, provided the original author and source are credited. 
(shock advertising/ shockvertising) and won awards for heightening public awareness about social issues. This approach, in turn, inspired public health campaigns such as road safety, AIDS prevention and anti-smoking.

In public health initiatives, the use of the fear appeals in the form of threatening health messages, is commonly used as a strategy for health promotion, disease prevention and adoption of behavior within a population (Brown \& Whiting, 2014; Simpson, 2017; Sweene \& Stephens, 2013). This tactic involves using images or messages to elicit negative emotions such as anxiety, in the expectation that the target audience will be motivated to adopt the recommended health behaviors (Brown \& Whiting, 2014). According to Kelly (2000) many of the diseases that cause premature illness and death, such as, cancer, heart diseases and AIDS, can be prevented if people change their behavior to reduce their risk of contracting the illness.

In December 2019, coronavirus disease 2019 (COVID-19), a new human disease, was discovered in Wuhan, the capital of Hubei Province in Central China. The disease is highly contagious, which means it can be spread, directly or indirectly, from one person to another. Densely populated communities or cities enhance its quick spread (WHO, 2020). The virus is spread through respiratory droplets transmitted into the air from coughing or sneezing, which people nearby can take in through their nose, mouth or eyes. It can also be transmitted when human beings touch surfaces that are contaminated with the virus and further, with their unclean hands, touch their eyes, nose and mouth (Africa Center for Disease Control and Prevention, 2020). To date, the disease has no cure or vaccine. Worldwide, millions of people have been infected and hundreds of thousands have lost their lives to the virus.

In Africa, the first case of COVID-19 was confirmed in Egypt on 14th February 2020 (Al Jazeera and News Agencies, 2020). The disease then spread to a number of other countries in the continent within weeks. Kenya first recorded its first COVID-19 positive case on the morning of 13th March 2020. As of 29th June 2020, the country had a total of 6,190 COVID-19 positive cases out of which 2,013 people had recovered from the disease. 144 people had also lost their lives to the virus (Ministry of Health, 2020). Out of the 47 counties in Kenya, Nairobi County had the highest number of COVID-19 positive cases, 3,098, out of 6,190 people who had tested positive, countrywide. Since Kenya recorded its first COVID-19 positive case, the government has put in place a number of preventive measures, some of which are meant to protect commercial motorcycle operators, commonly known as boda boda riders from contracting and spreading the virus, as they come into contact with many people in the course of their work.

The boda boda operators were ordered to frequently wash their hands with running water and soap or clean hands with alcohol-based sanitizer; put on masks and carry only one passenger at a time to enable them maintain physical distance (Ministry of Health, 2020). However, despite boda boda riders being ordered to adhere to the preventive measures, Mutahi Kagwe, who is the Cabinet Secretary of health said the government had noted with serious concern that the operators were not following the stipulated directives. The CS, thus, issued a strong warning that should the riders continue flouting the measures put in place, the government would not only ban operations for rogue riders, but the whole sector (Muriuki, 2020). The riders not only risk their bikes being impounded by the authority but also their livelihoods (Ministry of Health, 2020). This stern warning was meant to elicit fear which would in turn make boda boda riders adopt the recommended preventive measures. However, fear appeals can either be effective or ineffective in the acceptance of health messages and adoption of recommended behavior(s). Therefore, this study investigated the efficacy of fear appeals on the adoption of COVID-19 preventive measures among boda boda riders in Nairobi County, Kenya.

\section{THEORETICAL FRAMEWORK}

This study draws from the Health Belief Model (HBM). The HBM was developed in the 1950s by social psychologists Irwin M. Rosenstock, Godfrey M. Hochbaum, S. Stephen Kegeles and Howard Leventhal at the U.S. Public Health Service. The model was developed in an effort to determine why most of the general public was not involved in disease prevention programs, specifically the screening programs for tuberculosis (Janz \& Beker, 1984; Louise, 2016). HBM, comprises six components: (1) perceived susceptibility refers to an individual's perception of the threat occurring, (2) perceived severity refers to an understanding of the seriousness of a health situation or threat, (3) perceived benefit is the manner in which an individual perceives that a recommended action would reduce the risk of a health threat, (4) perceived barriers are the impediments to adopting recommended behavior, (5) cue to action is a trigger for prompting engagement in health promoting behavior, and (6) self-efficacy is the perceived ability to perform the recommended action. 
The health belief model is ideal for this study because it seeks to understand why individuals are willing or not willing to participate in preventive programs. The model indicates that while health messages may indicate a desired course of action for the audience, message recipients still need to have a reason to believe the message, understand why it is worthwhile to their personal lives and believe that recommended measures will have positive impact on their health (DuPre, 2010). More particularly, in regard to effectiveness of fear appeals and adoption of health preventive measures, the health belief model asserts that when message recipients are presented with a fear appeal, resulting feelings of susceptibility lead them to evaluate whether or not adopting the messages recommendations will protect them from the threat-related negative consequences. Fear appeals, according to De Hoog, Stroebe and De Wit (2007) and Witte and Allen (2000), are said to be effective if message recipients decide that adopting the recommended action(s) will protect them.

\section{LITERATURE REVIEW}

\subsection{EFFICACY OF FEAR APPEALS ON ADOPTION OF HEALTH PREVENTIVE MEASURES}

Fear appeals, "are persuasive messages that emphasize the potential danger and harm that will befall individuals if they do not adopt the messages recommendations" (Dillard, Plotnick, Godbold, Freimuth, \& Edgar, 1996; Maddux \& Rogers, 1983). A fear appeal, according to Gore, Madhavan, Curry and McClurg (1998) comprises of three main components: fear, threat and perceived efficacy. Fear is a negative emotional reaction that is usually accompanied by heightened physiological arousal to a perceived threat (Gore et al., 1998). Fear emanates from a threat on an individual's well-being, which in turn motivates the person to align their attitudes and/or behaviors with those recommended in the message (Maddux \& Rogers, 1983; Williams, 2012; Witte, 1992). Threat is an external stimulus that creates a perception in message receivers that they are susceptible to some negative situation or outcome (Gore et al., 1998). A threat is a trigger to the emotion of fear to occur. This reaction of fear emanating from threat is causal in nature (Bates, 2014). Perceived efficacy, on the other hand, is an individual's belief that the recommendations in the message can be implemented and will effectively reduce the threat depicted (Gore et al., 1998).

The desired outcome of a fear appeal is the acceptance of the message and adoption of its recommendations by the target recipients. However, fear appeals can either be effective or ineffective. Additionally, they can have positive effects, while others have null effects or negative effects (De Hoog et al., 2007; Peters, Ruiter, \& Kok, 2012; Witte \& Allen, 2000). The efficacy of fear appeals can be determined by the amount of fear a message is meant to arouse in the recipient. Two competing theories, the linear and curvilinear models, make predictions about the amount of depicted fear. The linear model predicts that high depicted fear is more effective in increased adoption of a message's recommendations than moderate depicted fear (Witte \& Allen, 2000). However, the curvilinear model predicts that high levels of depicted fear is less effective in adoption of a message's recommendations than moderate levels of depicted fear (Hovland, Janis \& Kelly, 1953; Janis \& Feshbach, 1953).

According to Witte and Allen (2000), fear appeals are more effective when they involve health related behaviors, including messages which assure recipients that they are capable of performing the appeal's recommended actions (self-efficacy) and/or that performing the recommendations will result in desirable consequences. On the same note, Rogers (1983) found that effective fear appeals: "(1) have a message that is credible as it warns [that] if the current behavior continues, the probability of negative health consequences is high, and (2) the warning provides a person with an effective method of changing behavior that guarantees protection from the predicted aversive health outcome." Further, Robertson (1975) and Rothman, Martino, Bedell, Detweiler and Salovey (1999) assert that persuasive messages that recommend a one-time behavior (e.g. getting vaccinated), are likely to be adopted because they require less effort. On the other hand, behaviors that must be repeated over an extended period of time (e.g. exercising), are not likely to be adopted because more effort is needed.

Similar to Robertson (1975) and Rothman et al. (1999) assertions, Tannenbaum, et al. (2015) conducted a metaanalysis study on fear appeals effectiveness for influencing attitudes, intentions and behaviors. The meta-analysis included 127 articles (9\% unpublished) yielding 248 independent samples collected from diverse populations. Study findings revealed that effectiveness of fear appeals increased when the message included efficacy statements, depicted high susceptibility and severity, recommended one-time only (versus repeated) behaviors and a target audience that included a large percentage of female message recipients. An experimental study on fear, threat and 
perceptions of efficacy from frightening skin cancer messages, was conducted by Stephen and Witte (1998). The results indicated that highly threatening fear appeals, were more effective when combined with a strong efficacy message emphasizing the effectiveness of the recommended behavior.

Contrary to fear appeals that achieve the desired outcome(s), ineffective fear appeals contain messages that do not produce fear (Shen \& Dillard, 2014). Fear appeals may have negative consequences for recipients with low selfefficacy, as the message may strengthen the recipient's belief that they cannot avoid health threats (Hastings, Stead, $\&$ Webb, 2004). In addition, the fear appeal may psychologically reduce the evoked fear by opposing the message. Such defense mechanisms can make the recipient deny the message by viewing it as not true. This mechanism results in the fear diminishing and the message not being taken seriously (Lewis, Watson, Tay \& Witte, 2007). Further, Shen and Dillard (2014) noted that, people who experience the highest degree of fear are the same persons who will most likely reject the message.

Muthusamy, Levine and Weber (2009) conducted an experimental study on the role of fear-inducing message content in a high fear context, specifically that of HIV/AIDS pandemic in Namibia. A total of 434 male and female undergraduate students enrolled in various departments in the University of Namibia (UNAM) participated in the study. Findings revealed that, fear appeals have little substantive yield in scaring those already scared. In addition, a survey on the use of fear appeal on antismoking advertising campaigns on Turkish youth was conducted by Akyuz (2017). Using questionnaires to collect data from smoker and non-smoker individuals, the study found that advertisements that contain fear appeals that stimulate quit behavior among cigarette users are not effective. However, fear appeals may be effective in creating avoidance to start cigarette use among potential young cigarette users.

\subsection{COVID-19 PREVENTIVE MEASURES}

Since the outbreak of the coronavirus disease, the World Health Organization has stipulated a number of preventive measures to curb the life-threatening disease. The measures include: (1) regular and thorough cleaning of hands with running water and soap or alcohol-based hand sanitizer, (2) maintenance of one meter distance between oneself and another, (3) avoiding crowded places, (4) avoiding touching of eyes, nose and mouth, (5) covering the mouth and nose with a bent elbow or tissue when coughing or sneezing, (6) staying at home if one is unwell, and (7) if one has a cough, fever and difficulty in breathing, they should seek medical attention (WHO, 2020).

In addition to the WHO preventive measures, most countries in the world that are experiencing the COVID-19 outbreak, have implemented more measures. For example, on 21 ${ }^{\text {st }}$ March 2020, the Italian Prime Minister Giuseppe Cone, announced a number of restrictions which were imposed on the country's citizens. The restrictions included; closure of all non-essential production services, bars and restaurants, prohibition of outdoor activities, visits to the park, gardens and movement of persons entering or leaving some regions of Southern Italy, such as Calabria and Campania (Lorenzo \& Trolio, 2020). In Spain, on the 14th of March 2020, limited movement of persons, suspension of all on-site educational activities, and closure of public retail establishments, bars, hotels and restaurants, were the adopted measures to contain the progress of the disease (Rodl \& Parter, 2020). In India, social isolation and lockdown, were the two main preventive measures used by the government (Tomar \& Gupa, 2020).

In Africa, presidents of countries such as South Africa, Rwanda and Uganda ordered nationwide lockdowns in a bid to combat further spread of the deadly coronavirus. However, rather than a nationwide lockdown, the president of Ghana ordered a three-week lockdown in its two biggest cities, Accra and Kumasi (CGTN, 2020). In Kenya, a number of mitigation measures were put in place. Some of these measures include: Closure of all schools and institutions of learning, suspension of all gatherings, meetings and events, an everyday dusk to dawn curfew, cancellation of all passenger flights, regular handwashing, wearing of masks, maintenance of social distance (the one-meter distance rule) and restricted movement in and out of the Nairobi Metropolitan area.

\subsection{USE OF FEAR APPEALS IN THE ADOPTION OF COVID-19 PREVENTIVE MEASURES}

In order to make people adopt the various COVID-19 preventive measures, different governments introduced fear appeals in the form of threats, fines and arrests to its citizens. For instance, provincial police in Ontario, a province in east-central Canada, warned that people would face fines for violating orders to close certain businesses 
as a way of limiting gatherings (National Post, 2020). In the United Arab Emirates, on $20^{\text {th }}$ May 2020, less than a month after partially relaxing restrictions, the government revised some of its penalties. This was as a result of an increase in infections believed to have stemmed from people who had violated the already set COVID-19 preventive measures. Some of the penalties included 10,000 dirhams $(\$ 2,722.59)$ fine for those found hosting parties with each attendee having to pay 5,000 dirhams. A daily national curfew that was initially shortened by two hours, was also extended back to its original duration lasting from 8.00 p.m. to 6.00 a.m. (Abigail, 2020).

In Uganda, as President Yoweri Museveni announced tougher measures in an address to the nation, he also warned that he would act harshly against citizens who would disregard his directives. Further, the president also threatened to severely punish police and army officers caught beating people who were not adhering to the preventive measures (Olukya, 2020). Similarly, the Kenyan government signed into law the rule that says persons who breach the travel, mass gatherings and isolation rules will face a fine of up to Kenya shillings 50,000, or a jail term of up to three years or both in line with the public health law. In addition, the government in its social distancing measures stated that travelers coming into the country would be put under mandatory quarantine at their own cost. In a bid to make Kenyans comply with the COVID-19 preventive measures, the Health Cabinet Secretary, Mutahi Kagwe said, "Much to our disappointment, the majority of people continue to ignore measures spelt out earlier. If we behave normally, this disease will treat us abnormally" (Mutai, 2020).

\section{METHODOLOGY}

\subsection{STUDY DESIGN}

Case study research design which focused only on boda boda riders was used in this study. The design was appropriate because the study sought to investigate the efficacy of fear appeals on the adoption of COVID-19 preventive measures among boda boda riders in Nairobi County.

\subsection{POPULATION OF THE STUDY}

The population of the study targeted all the boda boda riders operating in Nairobi County. Of importance to note is that the researcher found no official statistics on the exact number of boda boda riders operating in Nairobi County. According to the Independent Electoral and Boundaries Commission (2013), Nairobi County is divided into 17 constituencies namely: Westlands, Dagoretti North, Dagoretti South, Langata, Kibra, Kasarani, Roysambu, Starehe, Ruaraka, Mathare, Embakasi North, Embakasi East, Embakasi South, Embakasi West, Embakasi Central, Makadara and Kamukunji. All constituencies in Nairobi County were included, such that the findings of the study formed a representative section of the entire county.

\subsection{SAMPLE AND SAMPLING TECHNIQUE}

This study used the qualitative sampling technique. A qualitative sample size is best determined by the time allocation, resources available, the objectives of the study (Patton, 1990) and data saturation (Fusch \& Ness, 2015). Different scholars give varying numbers for participants to be interviewed in a qualitative study. For example, Guest, Bunce and Johnson (2006) found that 12 interviews conducted from a homogeneous sample is enough to reach data saturation. Similarly, Kuzel (1992) recommended 6-12 interviews for a homogeneous sample. However, Green and Thorogood (2004) noted that most qualitative researchers experienced data saturation after interviewing approximately 20 participants belonging to one analytical relevant category. Therefore, based on Green and Thorogood (2004), Guest et al. (2006) and Kuzel (1992) recommendations, this study interviewed one boda boda rider from each of the 17 constituencies in Nairobi County totaling to a sample size of 17 respondents.

Convenience sampling was used to identify boda boda riders who were available and willing to participate in the study. In order to achieve a sample size of 17 respondents, the researcher contacted friends, colleagues and relatives who reside in different constituencies in Nairobi County to help in identifying boda boda operators in their area of residence who were willing to participate in the telephone interview. 
Efficacy of Fear Appeals on Adoption of Covid-19 Preventive Measures: A Case of Boda Boda Riders in Nairobi County, Kenya

\subsection{DATA COLLECTION}

The researcher used qualitative data collection methods. The main data collection tool was telephone interviews with boda boda riders. Advantages of telephone interviews include decreased cost and travel, ability to reach respondents who are dispersed in a large geographical area and enhanced interviewer safety (Aday 1996; Bernard, 2002). In this study, telephone interviews were the most appropriate data collection tools because they enabled the researcher to work from home and have physical distance with the respondents. This, in turn, prevented the researcher and respondents from contracting and spreading the coronavirus disease during data collection.

\section{FINDINGS AND DISCUSSION}

\subsection{DEMOGRAPHIC INFORMATION}

All the respondents in the study were males. This shows that the boda boda business sector is dominated by males. In terms of the age of the boda boda riders, most of them ranged between 30-39 years while a minority were between 40-49 years and one was 24 years. This indicated that majority of the boda boda riders are youths. In addition, majority of the respondents were married while a minority were single. This shows that the operators rely on the boda boda business as a source of income to be able to take care of their family financial needs. Majority of the riders had an experience of between one to ten years in the boda boda business, while a minority had 11-20 years, experience. This indicates that the respondents were in the boda boda business long enough to be able to provide relevant information for the study. Majority of the boda boda riders had attained primary school education followed by those with secondary school education. Further, one rider was a university graduate and another one had no formal education. This shows that most boda boda riders have low levels of education which reduces their chances of getting jobs in the formal sector.

\subsection{PERCEIVED THREATS}

All the seventeen Boda boda operators in this study, were in consensus that they were at the risk of contracting the coronavirus disease, being arrested, motorcycles being impounded, fined and/or being quarantined if they did not adhere to the COVID-19 preventive measures. However, the riders emphasized that they were more susceptible to contracting the virus because in a day, they carry many people including taking the sick to hospital.

With regard to whether the coronavirus disease would have serious effects on their lives should they contract it, all respondents asserted that the disease was a serious threat to their health and lives. One respondent said, "Going by what we see in the international news channels regarding the coronavirus disease, it is dangerous because it is life threatening. Many people who live abroad have lost their lives to the disease."

When the respondents were asked if they had received warnings not to flout the preventive measures, study respondents said that the health CS, Mutahi Kagwe, had on several occasions warned that the coronavirus disease is a serious and deadly disease. The riders also said that they had been warned that should they not adhere to the preventive measure, they risked being arrested and taken for a fourteen days mandatory quarantine, motor bikes being impounded, paying a penalty of 20,000 shillings or a jail term of six months. One respondent said:

The government told us it's closely watching us. If we don't follow the stipulated measures, it will take tougher measures on us. We don't know what the measures will entail. Maybe it will give a directive that boda bodas should not operate anymore.

Findings revealed that respondents were susceptible to contracting the coronavirus disease, police arrests, fourteen days mandatory quarantine, motorcycles being impounded and payment of fines, if they did not adopt the COVID-19 preventive measures. However, the coronavirus disease posed a more serious threat to the riders' health and lives. These findings were in tandem with those of Tannenbaum, et al. (2015) who found that the effectiveness of fear appeals increased when the message depicted high susceptibility and severity. Further, the current research revealed that the government, which is considered a credible source of information, had issued threat messages to boda boda operators flouting regulations set in place to contain the spread of the coronavirus. The warnings, in turn, made the boda boda riders adopt the COVID-19 preventive measures. This finding support those of Rogers (1983) 
who found that effective fear appeals have a message that is credible as it warns if the current behavior continues, the probability of negative health consequences is high.

\subsection{FEAR EMANATING FROM THE PERCEIVED THREATS}

All the respondents said that they feared contracting the coronavirus disease because the disease has neither cure nor vaccine and that one can either get well or lose their life. The riders also feared being taken into mandatory quarantine at one's own expense, spreading the virus to their wives and children, inability to work and earn money to provide for family needs. With regard to the level of fear that emanated from the perceived threats, all respondents asserted that the level of fear they experienced was high. One respondent said: "Nobody wants to die. Contracting the coronavirus disease, according to me, is like a death sentence."

The study showed that boda boda riders' perceived threats of contracting and spreading the coronavirus disease, being taken into mandatory quarantine at one's own expense, inability to work and earn money to sustain their family needs while sick, elicited high levels of fear that made the operators adopt the COVID-19 preventive measures. This finding is in agreement with the linear model of fear appeals that predicts that high levels of fear increase motivation to adopt the message's recommendations (Witte \& Allen, 2000).

\subsection{PERCEIVED EFFICACY}

To avert the contraction and spread of the coronavirus disease, all the respondents stated that they together with their passengers, wear masks, keep distance, wash hands with soap if they are near a handwashing station and if not, they use alcohol-based hand sanitizers. The riders also carry only one passenger at a time to enable them to have physical distance with the passenger. One rider said, "One of the boda boda regulations is that we should only carry one passenger. Therefore, even before the coronavirus pandemic, I have always been carrying one passenger at a time." However, some riders asserted that maintaining physical distance when carrying a passenger was difficult. The passenger is usually pushed forward thus having contact with the rider, whenever the rider slows down after riding at a high speed. On the same note, other riders pointed out that a motorcycle is not big enough to enable the rider and passenger maintain one or one-and-a-half-meter physical distance.

The respondents also stated that they believed adhering to the measures reduced the risk of being arrested, quarantined and contracting the coronavirus disease. One boda boda rider said:

From the time Kenya recorded its first coronavirus positive case, I have carried many passengers. Since I strictly follow the preventive measures, I have so far not contracted the disease. I, therefore, believe that the preventive measures have protected me from contracting the virus.

Another respondent said:

The coronavirus preventive measures have protected us not only from contracting the virus but other diseases as well. For example, frequent washing of hands helps us to maintain cleanliness and prevents us from contracting the cholera disease. In addition, wearing of masks has helped us not to inhale dust when riding on dirty roads and not to inhale cold air while riding at a high speed. This prevents us from contracting pneumonia.

Findings of the study revealed that all the boda boda riders adopted the covid-19 preventive measures. The measures include carrying one passenger, wearing masks, keeping distance, washing hands with soap if they are near a handwashing station and if not, they use alcohol-based hand sanitizers. The respondents also stated that they believed adhering to the measures reduced the threat of contracting the coronavirus disease, being arrested and quarantined. These findings are in agreement with those of Rogers (1983) and Witte and Allen (2000) who found that effective fear appeals provide an effective method of changing behavior and guarantee protection from the predicted aversive health outcome.

\section{CONCLUSION}

In conclusion, this study revealed that fear appeals were effective in the adoption of COVID-19 preventive measures among boda boda riders in Nairobi County. The boda boda riders' felt that they were susceptible to the 
coronavirus disease, police arrests, fourteen days mandatory quarantine, motorcycles being impounded and payment of fines, if they did not adopt the COVID-19 preventive measures. Moreover, the riders believed that COVID19 posed a more serious threat to their health and lives. The feelings of susceptibility to the threats, in turn, elicited high levels of fear among the boda boda operators. The COVID-19 preventive measures, also, provided the riders with an effective method of changing behavior which they believe will protect them from contracting the virus.

\section{RECOMMENDATION}

Drawing from the conclusions, this paper recommends that the government should frequently give boda boda riders masks and hand sanitizers. This will motivate the operators to continue adopting the COVID-19 preventive measures because behaviors that must be repeated over an extended period of time require more effort. Further, more communication campaigns should be developed and conducted on COVID-19 awareness and prevention among boda boda riders.

\section{SOURCES OF FUNDING}

None.

\section{CONFLICT OF INTEREST}

None.

\section{ACKNOWLEDGMENT}

I am thankful to all boda boda riders who took part in the study.

\section{REFERENCES}

[1] Abigail, N. G. (2020). An \$800 fine if you don't wear a mask: The UAE introduces new coronavirus penalties. Retrieved from https://www.cnbc.com/2020/05/19/coronavirus-the-uae-expands-curfew-introducesnew-penalties.html

[2] Aday, L. A. (1996). Designing and conducting health surveys. San Francisco: Jossey-Bass.

[3] Africa Center for Disease Control and Prevention (Africa CDC). (2020). Coronavirus Disease (COVID-19). Retrieved from https://africacdc.org/covid-19/

[4] Akyuz, A. (2017). The use of fear appeal for anti-smoking adverting campaigns: A survey on Turkish youth. International Journal of Social Science and Economic Research, 2(2), 2434-2449. Retrieved from https://www.researchgate.net/publication/319911452

[5] Al Jazeera and News Agencies. (2020). Egypt confirms coronavirus case, the first in Africa. Retrieved from https://www.aljazeera.com/news/2020/02/egypt-confirms-coronavirus-case-africa200214190840134.html

[6] Bates, M. E. (2014). Fear as a motivator of health campaigns: An examination of fear appeals messaging ang skin cancer prevention. (A Master's thesis, Clemson University). Retrieved from https://pdfs.semanticscholar.org/1a2d/3c18339b57afe2d1ddcdf02ddbf531ba2b12.pdf

[7] Bernard, H. (2002). Research methods in anthropology: Qualitative and quantitative approaches. Lanham, MD: Altamira.

[8] Brown, S. L., \& Whiting, D. (2014). The ethics of distress: Towards a framework for determining the ethical acceptability of distressing health promotion advertising. International Journal of Psychology, 49(2), 89-97. doi: 10-1002/ijop.12002

[9] China Global Television Network (CGTN). (2020). Ghana is the first African country to lift its coronavirus lockdown. Retrieved from https://newsaf.cgtn.com/news/2020-04-21/Ghana-is-the-first-African-countryto-lift-its-coronavirus-lockdown-PR021Y9MZy/index.html 
[10] Dahl, W. D., Frankenberger, K. \& Manchanda, V. (2003). Does it pay to shock? Reactions to shocking and nonshocking content among university students. Journal of Adverting Research, 43(3), 268-280. http://dx.doi.org/10.1017/S0021849903030332

[11] De Hoog, N., Stroebe, W., \& De Wit, J. B. F. (2007). The impact of vulnerability to and severability of a health risk on processing and acceptance of fear-arousing communications: A meta-analysis. Review of General Psychology, 11(3), 258-285. http://dx.doi.org/10.1037/1089-2680.11.3.258

[12] Dillard, J. P., Plotnick, C. A., Godbold, L. C., Freimuth, V. S., \& Edgar, T. (1996). The multiple effective outcomes of AIDS PSAs: Fear appeals do more than scare people. Communication Research, 23(1), 44-72. https://dx.doi.org/10.1177\%2F009365096023001002

[13] Di Lorenzo, G., \& Di Trolio, R. (2020). Coronavirus Disease (COVID-19) in Italy: Analysis of risk factors and proposed remedial measures. Frontiers in Medicine, 7, 140. Retrieved from https://www.frontiersin.org/articles/10.3389/fmed.2020.00140/full

[14] DuPre, A. (2010). Communicating about health: Current issues and perspectives. New York: Oxford University Press.

[15] Fusch, P. I., \& Ness, L. R. (2015). Are we there yet? Data saturation in qualitative research. The Qualitative Report, 20(9), 1408-1416. Retrieved from https://cpb-us-east-1juc1ugur1qwqqqo4.stackpathdns.com/sites.nova.edu/dist/a/4/files/2015/09/fusch1.pdf

[16] Gore, P., Madhavan, S., Curry, D., \& McClurg, G. (1998). Persuasive messages. Marketing Health Services, 18(4), 32-43.

[17] Green, J., \& Thorogood, N. (2004). Qualitative methods for health research. London; Sage.

[18] Guest, G., Bunce, A., \& Johnson, L. (2006). How many interviews are enough? An experiment with data saturation and variability. Field Methods, 18(1), 59-82. https://doi.org/10.1177/1525822X05279903

[19] Hastings, G., Stead, M., \& Webb, J. (2004). 'Fear appeals in social marketing: strategic and ethical reasons for concern.' Journal of Psychology and Marketing, 22(11), 1114-1122.

[20] Hovland, C., Janis, I. L., \& Kelly, H. (1953). Communication andpersuation. New Haven, CT: Yale University Press.

[21] Independent Electoral and Boundaries Commission (IEBC) (2013). 4Th March 2013 general election: Election data. Retrieved from https://www.iebc.or.ke/uploads/resources/EIqEo3LuiB.pdf

[22] Janis, I. L., \& Feshbach, S. (1953). Effects of fear-arousing communications. Journal of Abnormal and Social Psychology, 48(1), 78-92. doi: 10.1037/h0060732.

[23] Janz, N. K., \& Beker, M. H. (1984). The health belief model: A decade later. Health, Education \& Behavior, 11(1), 1-47. doi: 10.1177/109019818401100101.

[24] Kelly, J. A. (2000). Behavior changes \& disease prevention: MCW research shows effectiveness of HIV/AIDS risk reduction interventions. Wisconsin Medical Journal, 99 (1), pp. 41-43.

[25] Kuzel, A. J. (1992). Sampling is qualitative inquiry. In B. F. Crabtree \& W. L. Miller (Eds.), Research methods for primary care, Vol. 3. Doing qualitative research (p. 31-44). Sage Publication, Inc.

[26] Lewis, M., Watson, B., Tay, R., \& Witte, M. (2007). The role of fear appeals in improving driver safety: a review of the effectiveness of fear arousal (threat) appeals in road safety advertising. International Journal of Behavioral and Consultation Therapy, 3(1), 203-222.

[27] Louise, J. P. (2016). Examining constructs of the Health Belief Model as predicator of Haitian men's men intention regarding prostate cancer screening. (A doctoral dissertation, Barry University). Retrieved from https://sigma.nursingrepository.org/bitstream/handle/10755/621199/Louis_Redacted.pdf

[28] Maddux, J. E., \& Rogers, R. W. (1983). Protection motivation and self-efficacy: A revised theory of fear appeals and attitude change. Journal of experimental Social Psychology 14, 469-479. Retrieved from https://www.academia.edu/18674921/Protection_motivation_and_selfefficacy_A_revised_theory_of_fear_appeals_and_attitude_change

[29] Ministry of Health (MOH). (2020). Government warn boda boda riders flouting rules in Nairobi. Retrieved from https://www.health.go.ke/government-warn-boda-boda-riders-flouting-rules-nairobi-thursdayapril-9-2020/

[30] Muriuki, B. (2020, April 9). Gov't threatens to barn boda boda operations for flouting coronavirus restrictions. Citizen digital. Retrieved from https://citizentv.co.ke/news/govt-threatens-to-ban-boda-bodaoperations-for-flouting-coronavirus-restrictions-329454/ 
Efficacy of Fear Appeals on Adoption of Covid-19 Preventive Measures: A Case of Boda Boda Riders in Nairobi County, Kenya

[31] Mutai, E. (2020, March 23). Fines, 3-year jail term for breaking virus control rules. Business Daily. Retrieved from https://www.businessdailyafrica.com/news/Fines-jail-term-for-breaking-virus-controlrules/539546-5500732-11t25jc/index.html

[32] Muthusamy, N., Levine, T. R., \& Weber, R. (2009). Scaring the already scared: some problems with HIV/AIDS fear appeals in Namibia. Journal of Communication, 59(2), 317-344. https://msu.edu/ levinet/Fear\&AIDs_JOC.pdf

[33] National Post. (2020). COVID-19 Government threaten fines, arrests, if people refuse to follow orders to Isolate and social distance. National Post. Retrieved from https://nationalpost.com/news/governmentsthreaten-fines-arrest-if-orders-to-distance-and-isolate-not-followed

[34] Olukya, G. (2020). Uganda tightens measures after COVID-19 cases rise: President vows harsh crackdown on those who disregard his instructions. Retrieved from https://www.aa.com.tr/en/africa/uganda-tightensmeasures-after-covid-19-cases-rise/1797954

[35] Patton, M. (1990). Qualitative evaluation and research methods. SAGE Publications, inc.

[36] Peters, G. J., Ruiter, R. A., \& Kok, G. (2012). Threatening communication: a critical re-analysis and a revised meta-analytic test of fear appeal theory. Health Psychology Review, 7(sup1), S8-S31. doi: 10.1080/17437199.2012.703527

[37] Robertson, L. S. (1975). Behavioral research and strategies in public health: A demur. Social Science \& Medicine (1967), 9(3), 165-170. http://dx.doi.org/10.1016/0037-7856(75)90053-0

[38] Rodl, C. \& Parter (2020). Measures taken by the government of Spain against the health alert caused by COVID-19. Retrieved from https://www.frontiersin.org/articles/10.3389/fmed.2020.00140/full

[39] Rogers, R. W. (1983). Cognitive and physiological processes in fear appeals and attitude change: A revised theory of protection motivation. Social psychophysiology: A source book, 153-176.

[40] Rothman, A J., Martino, S. C., Bedell, B. T., Detweiler, J. B., \& Salovey, P. (1999). The systematic influence of gain and loss-framed messages on interest in and use of different types of health behavior. Personality \& Social Psychology Bulleting, 25(11), 1355-1369. http://dx.doi.org/10.1177/0146167299259003

[41] Shen, L., \& Dillard, J. P. (2014). Threat, fear, and persuasion: Review and critic of questions about functional form. Review of Communication Research, 2, 94-114. Retrieved from https://www.rcommunicationr.org/index.php/articles/volume2-2014/finish/13/26

[42] Simpson, J. K. (2017). Appeal to fear in health care: appropriate or inappropriate? Chiropractic \& Manual Therapies, $\quad$ (25)1, $27 . \quad$ Retrieved from https://www.researchgate.net/publication/319940664_Appeal_to_fear_in_health_care_Appropriate_or_ina ppropriate

[43] Stephen, M. T., \& Witte, K. (1998). Fear, threat and perceptions of efficacy from frightening skin cancer messages. Public Health Review, 26(2), 147-174. Retrieved from http://www.uky.edu/ mstep1/home/skincan.html

[44] Sweene, K., \& Stephens, S. (2013). The use of fear appeals to communicate public health messages. Irish Business Journal, 8(1), 87-96. Retrieved https://www.researchgate.net/publication/331319860_The_use_of_fear_appeals_to_communicate_a_publi c_health_message

[45] Tannenbaum, M. B., Hepler, J., Zimmerman, R. S., Saul, L., Jacobs, S. Wilson, K., \& Albarracin, D. (2015). Appealing to Fear: A meta-analysis of fear appeal effectiveness and theories. American Psychological Association, 141(6), 1178. Retrieved from https://www.apa.org/pubs/journals/releases/bul-a0039729.pdf

[46] Thompson, L. E., Barnett, J. R., \& Pearce, J. R. (2009). Scared straight? Fear appeal anti-smoking campaigns, risk, self-efficacy and addiction. Health, Risk and Society, 11(2), 181-196.

[47] Tomar, A., \& Gupa, N. (2020). Prediction for the spread of COVID-19 in India and effectiveness of preventive measures. Science of The Total Environment, 138762.

[48] Williams, K. C. (2012). Fear appeal theory. International Journal of Economics and Business Research, 5, 6382. Retrieved from https://www.researchgate.net/publication/265807800_Fear_Appeal_Theory

[49] Witte, K. (1992). Putting the fear back into fear appeals: The extended parallel process model (EPPM). Communication Monographs, 59(4), 329-349.

[50] Witte, K., \& Allen, M. (2000). A meta-analysis of fear appeals: Implications for effective public health campaigns. Health Education \& Behavior, 27(5), 591-615.

International Journal of Research -GRANTHAALAYAH 
[51] World Health Organization (WHO). (2020). Coronavirus disease (COVID-19) advice for the public. Retrieved from https://www.who.int/emergencies/diseases/novel-coronavirus-2019/advice-for-public. 